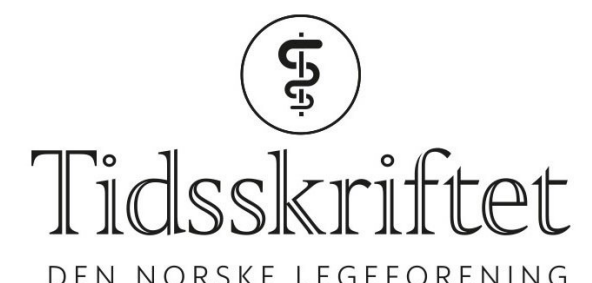

DEN NORSKE LEGEFORENING

\title{
Fastlegen er viktig når barn er pårørande
}

DOKTORAVHANDLINGER

FRØYDIS GULLBRA

E-post: frogull@online.no

Ved sjukdom eller rusproblem hjå foreldre har fastlegen eit unytta potensial for å hjelpe barna, både ved å anerkjenne livssituasjonen, ved rådgjeving og informasjon.

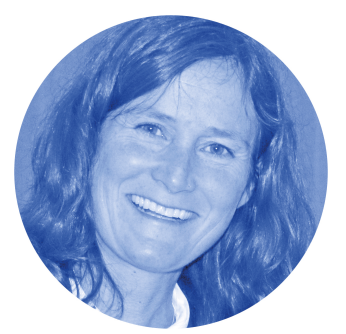

Foto: Kulshamar Foto

Psykisk sjukdom, alvorleg somatisk sjukdom eller rusproblem hjå foreldre kan gå utover barna. Dei får ofte ekstra omsorgsoppgåver, får kvardagen endra og har bekymringar. Dersom dei har slike byrder i lang tid, kan det gå utover deira eiga helse. Ved tidleg å identifisere og setje inn tiltak der det trengst, kan ein betre livskvaliteten og hindre helseplager hjå desse barna. Lovendringar frå 2010 pålegg helsepersonell å syte for at desse barna får informasjon og nødvendig oppfølging.

I denne studien har eg intervjua fastlegar, ungdom med sjuke foreldre og foreldre som er sjuke om kva rolle fastlegen kan ha for å hjelpe barn som pårørande. Eg finn at fastlegen er i ein god posisjon for å kunne identifisere hjelpebehov og for å sette i verk hjelpetiltak likevel blir barna ofte oversett. Ungdommar treng meir informasjon, sjuke foreldre kan ha bruk for råd og støtte. Både ungdommane og dei sjuke foreldra treng at nokon veit at dei er i ein vanskeleg situasjon, samstundes som dei prøver skape ein vanleg kvardag. Dei ynskjer at fastlegen tek opp tema om korleis den endra veremåten til sjuke foreldre kan verke inn på barna.

Fastlegar kan ved å tematisere situasjonen til barna overfor foreldre som slit med rus eller alvorleg sjukdom sørge for at færre barn som treng hjelp blir «usynlege». Samarbeid med andre aktørar i nettverk og hjelpeapparat kan vere nyttig der det trengst tiltak. 


\section{Disputas}

Frøydis Gullbrå disputerte for ph.d.-graden ved Universitetet i Bergen 30.5.2017. Tittelen på avhandlingen er Children as next of kin and the general practitioner: a qualitative study about the general practitioner's opportunities to help.

Publisert:30. oktober 2017. Tidsskr Nor Legeforen. DOI: 10.4045/tidsskr.17.0784

(C) Tidsskrift for Den norske legeforening 2020. Lastet ned fra tidsskriftet.no 